\title{
Asking about Content and Adding Content: two Patterns of Classroom Interaction
}

\author{
Preguntar y añadir contenido: dos patrones de interacción \\ en el aula
}

\author{
Edgar Lucero Babativa \\ Universidad Santo Tomas \\ Bogotá, Colombia \\ E-mail: edgarlucerob@hotmail.com
}

Received 24- Aug- 11 / Accepted 10 - May -12

\section{Abstract}

This research project focuses on identifying and describing the interactional patterns and the speech acts that emerge and are maintained through teacher-student interactions in a university-level EFL Pre-intermediate class. This work also analyzes how these patterns potentially influence the participants' interactional behavior. This study then answers two questions: what interactional patterns emerge and how they are structured in interactions between the teacher and the students in the EFL class? And, how can the utterances that compose the interactional patterns potentially influence both interactants' interactional behavior in the EFL class? The description and analysis of the problem follow ethnomethodological conversation analysis. The findings show that there are two main interactional patterns in the EFL class observed for this study: asking about content, and adding content. Both patterns present characteristic developments and speech acts that potentially influence the teacher and students' interactional behavior in this class. These findings serve as a reference and evidence for the interactional patterns that emerge in EFL classroom interaction and the influence they have on the way both interactants use the target language in classroom interaction.

Keywords: speech acts, teacher-student interaction, interactional patterns, interactional behavior.

\section{Resumen}

Esta investigación busca identificar y describir cuáles patrones de interacción con sus actos de habla emergen y se mantienen en la interacción profesor-estudiante en una clase de inglés como lengua extranjera de nivel pre intermedio a nivel universitario. Este trabajo analiza cómo estos patrones potencialmente influyen en la conducta de interacción de sus participantes dando respuesta a dos preguntas: ¿Qué patrones de interacción emergen en las interacciones entre el profesor y los estudiantes en una clase de EFL? Y ¿cómo los actos de habla de esos patrones de interacción potencialmente influyen en la conducta interaccional de ambos participantes en esta clase? El análisis es hecho bajo el enfoque etnometodológico del análisis de la conversación. Los resultados muestran que hay dos patrones de interacción principales en la clase observada: preguntar y agregar contenido. Ambos patrones presentan desarrollos y actos de habla característicos que potencialmente influyen en la conducta interaccional del profesor y los estudiantes en esta clase. Estos resultados bien pueden servir para referencia y evidencia de los patrones de interacción que emergen en las interacciones en una clase de inglés como lengua extranjera y la influencia que ellos puedan tener en la forma como ambos participantes usan esta lengua en la interacciones en clase.

Palabras clave: actos de habla, interacción profesor-estudiante, patrones de interacción, conducta interaccional. 


\section{Introduction}

The study of conversation in English as a Foreign Language (EFL) classroom has enormously contributed to understanding how interaction among teachers and students occurs in this setting. Research in this field has established important premises for understanding how EFL classroom interaction varies according to culture, content, and course activities. The present study analyzes how interaction occurs in an EFL classroom at the university level, focusing on how a language teacher and her students develop and maintain the speech acts that comprise certain interactional patterns, as well as the potential influence that these speech acts might exert on the participants'(the teacher and students') interactional behavior. Theory suggests that characteristic interactional patterns and speech acts may develop as part of the classroom interaction between teacher and students during classroom activities. Analyzing the specific moments and manners in which these patterns emerge, plus their potential influence on teacher and students' interactional behavior, is essential for understanding interaction overall.

Statement of problem: Existing studies have profoundly investigated the different interactional patterns that appear in EFL classroom interaction. These studies generally account for the structure of the interaction between the participants, the pragmatic responsibility for maintaining the conversation, and the analysis of the functionality of participants' utterances. Preliminary observations for this research also show these interactional patterns to be present. The most salient patterns mentioned in these studies that are present in the preliminary observations are:

- Students' opportunities to initiate or self-select when to participate (Garton, 2003).

- Elicit or request for explanation and clarification (Johnson, 1995; Long \& Sato, 1983, Leech, 1983; Lyster, 1998).
- Teacher's recognition of students' perspectives (Johnson, 1995).

- Repairs (Van Lier, 1988; Schegloff, 2000) or recasts (Long, 1996; Mackey \& Philp,1998; Ellis E Sheen, 2006).

- Teacher-initiated interaction (Ilatov, Shamai, Hertz-Lazarovitz, \& Mayer-Young 1998), teacher managing of interaction (see Long's interaction hypothesis, 1996), and interaction closings (Clark \& Schaefer, 1989).

The teacher and students continually coconstruct these interactional patterns in episodes and phases (Sinclair E Coulthard, 1975) and through conversation sequences, markers, and communicative strategies. Moreover, participants' use of distinctive utterances reflects particular structures of interactional patterns (such as the IRF sequence and adjacency pairs) as they (the utterances) function together to carry out the purpose of negotiating meaning.

The structures of the interactional patterns observed for the present study are clearly identifiable. They are alike to the structures suggested by the relevant literature. However, it is not plainly explicit at what moment these structures emerge, nor what influence the utterance-by-utterance development of these structures' might exert on teacher and students' interactional behavior in the EFL classroom. Therefore, it is important to identify what precise interactional patterns emerge, when they do, and how the utterances that compose these interactional patterns may influence interactants' interactional behavior in the EFL class under observation. Identifying these aspects can help to explain when distinctive interactional patterns emerge between teacher and the students in EFL classes, and how the structure of these patterns influences the interactional behavior of interactants in this type of class. For these reasons, this research study looks into the following questions: 
- What interactional patterns emerge in the teacher-student interactions of an EFL class, and how are these patterns structured?

- How can the utterances that compose the interactional patterns potentially influence both teacher and students' interactional behavior in the EFL classroom?

In order to answer these two research questions, this research project pursues three objectives. The first is to identify what interactional patterns with what utterances emerge in teacherstudent interactions in EFL class. The second objective is to describe when and how those interactional patterns are co-constructed and developed between the teacher and students. The third is to identify the potential influence that the utterances of those interactional patterns bear on both interactants' (teacher and students') interactional behavior.

\section{Literature Review}

Two main concepts underpin the present study's research questions and objectives. The first is the concept of utterances, which this research studies as speech acts (Searle, 1969). Speech acts tell about all those sorts of things a speaker can do with the performance of words in accordance with his/her intentions. The second is classroom interaction (Ellis, 1994), defined as the set of conversations or exchanges between the teacher and the students, or among the students, which occurs in the language classroom. The following section expands on the dimensions and types of these two concepts in order to explain how speech acts and classroom interaction constitute parts of the interactional patterns for the data in this research.

\section{Speech Acts}

The study of speech acts necessitates taking into account the context of the utterances, the conditions under which they occur, and the speaker's intentions (Searle, 1979). The context, conditions, and intentions in the data are established as follows: the context is the classroom where either the teacher or a student produces utterances in the TL through interacting with one another. The conditions are set up from three angles: the content of the interactions, the references indicated in the utterances, and the attempt at meaning-making in the emission of those utterances. The intentions arise in accordance with the conditions and help maintain the interaction's flowing in line with the implicit conventions of the task.

Given that the interactions are composed of the students' and teacher's utterances, it is possible that similar utterances within certain interactions may recur, or similar interactions from those utterances. In line with Searle (1969), speech acts can be "performed in certain ways under certain circumstances by those in certain institutional or social positions" (p. 149). This is the case for interactional patterns that emerge in the language classroom and the way the teacher and students construct their utterances for those interactional patterns. As the findings below will demonstrate, certain conditions and intentions generate utterances in the classroom which in turn give rise to recurring kinds of interactions between teacher and student, at the same time that similar utterances also appear within different kinds of constructed interactions.

However, a speech act in an utterance, from either the student or the teacher, are only recognizable if both interactants share, firstly, reciprocal understanding of the language used in the utterance, and secondly, how they must mutually develop the interaction in a context under certain conditions. Searle (1979) explains that the meaning of an utterance is dependent on the context, as the comprehension of this meaning resides in mutual knowledge from factual background information shared by the 
interactants in a conversation. For this research, this means that the interactional patterns that emerge in the classroom are put together by the students and the teacher, utterance by utterance, from a shared knowledge of, firstly, the meaning of the words that compose the utterance with an implicit intention, and secondly, the knowledge of how to reply to that utterance; both of these depend on the context and the conditions in which the utterances are said.

Following from this perspective, each utterance delivers meaning and intentions for interactional functions in context. Austin (1975) and Searle (1969) both affirm that a speech act is a social action performed via an utterance. Also, Searle (1979) states that a speech act is usually performed from the contextual elements that the situation provides. These elements help the hearer interpret the speaker's intentions.

For the language classroom which is the subject of this research, the speech act of an utterance, whether from the teacher or student, is an essential part in the ongoing construction of the interactions that emerge in class between these participants. This occurs because the speech act in any utterance contains the meaning and the intention that the speaker wants the hearer to understand. As a result of this understanding, the teacher and students assemble the interaction, an act continually in progress.

\section{Classroom Interaction}

Following Ellis, classroom interaction is understood as the events of communicative talk constructed between teacher and students in context, events which promote language learning and/or language use in a language classroom (1994). The role of this interaction is to engage the students in conversations to promote language learning and language use and to shape the learners' language in the classroom. These conversations, or exchanges, take place in different classroom situations (or contexts, as it is understood by Johnson (1995)) in which "the participants alternate turns speaking, appear to understand each other's intentions, and frame their responses accordingly" (Johnson, 1995, p. 4).

Two variables in classroom interaction are especially relevant to this research. These variables are, firstly, the content of classroom interaction, and secondly, the participants involved.

The content of classroom interaction is what is negotiated between the teacher and the students in classroom interaction. Ellis (1994) has conducted some studies for this variable, identifying four types of interaction in accordance with the content found in the classroom: mediumcentered goal, message-centered goal, activitycentered goal, and social goal interaction. In the same vein, Van Lier (1988) classifies classroom interaction into less/more topic-oriented or more/ less activity-oriented, depending on the focus of an activity or topic in the class. However, for Kasper (as cited in Seedhouse, 2004a, p. 135), there are only two types of content in a classroom interaction: language-centered (when the focus is the usage of the language) or content-centered (when the focus is the use of the language). Similarly, Hasan (as cited in Seedhouse, 2004a, p. 136) organizes classroom interaction into formal and informal: the former describes the structures and form of the target language (TL) and the latter the communication within it.

Considering the purposes of language use and learning in context, one sees how different types of classroom interaction arise according to the content variable. These different types give an account of what happens in the language classroom in terms of how content provided by the language molds interaction. As all of these types have in common a focus on the variable 
of content, they are useful models for analyzing classroom interaction in the present study.

The second variable of classroom interaction concerns the participants in the interaction. There is teacher-student interaction, student-student interaction, and student-teacher interaction. Johnson (1995) understands the first pair as a type of classroom interaction in which the teacher controls the content and structure through the use of language. In this type of interaction, the teacher uses language to lead the interaction with students, for example, by allowing them to take turns, to insist they participate in class activities, and to control the content of the interaction.

Student-student interaction, according to Johnson (1995), is the type of classroom interaction in which students use language for classroom learning and second language acquisition. In this type of interaction, the students, of their own accord or prompted by the teacher, create opportunities to use the language with one another in classroom activities.

The third type is student-teacher interaction. According to Richards and Lockhart (1994), this type of classroom interaction occurs when a student responds or volunteers to provide content during a discussion opened for using and learning the new language. In the student-teacher interaction, the student provides the content in the interaction; it is the student who creates opportunities to use the language in class.

In sum, research on classroom interaction understands this concept as the events of communicative talk constructed between teacher and students in a context of promoting language learning and/or language use in a language classroom; and then, as the set of conversations that come about in the language classroom with the aim of negotiating meaning while learning or using the TL.

Consistent with Kurhila (2006) and Gibbons (2006), this means that language always expresses meaning, intentions, and behavior in interactions within a context. When teacher and students interact through using language with these functions, they co-construct classroom interaction to communicate meaning and display intentions and behaviors in context.

When it is said that classroom interaction is composed of sets of conversations, it means that classroom interaction can be organized in episodes (Sinclair and Coulthard, 1975; Rivers, 1983; McCarthy, 1991) that identify the boundaries of every conversation or exchange that occurs in the classroom. As McCarthy (1991) further explains, the episodes that come to light in classroom interaction usually exhibit a beginning and an end, but their content can only be interpreted from the context in which they emerge. Researchers divide classroom interaction into units to cope with every micro-situation of meaning in context. These units indicate the boundaries within which participants negotiate meaning in the interaction. The way that meaning is understood relies on the context in which it is negotiated.

When the participants in a classroom interaction construct a conversation with the aim of negotiating meaning through the use of the TL, a set of communicative patterns emerge. Johnson (1995) defines communicative patterns as the shared understandings of how, when, where, and with whom language is to be used during interaction. This means, all those different ways in which communication is linked and organized within an interaction.

By identifying the episodes of interaction between teacher and students as they negotiate meaning, this research project presents an accurate picture of interactional patterns and their speech acts that construct the units of discourse in classroom interaction. In addition, the episodes show which forms of talk are most central and 
practiced in the group observed, and at what moments they appear during the class.

\section{Methodological Framework}

Twelve sessions were observed from the beginning to end of an academic period of sixteen weeks. The sessions were each 2 hours of observation of a university-level class of preintermediate EFL students majoring in business management, accounting, and economics. The group consisted of 24 students whose ages ranged from 19 to 26 years old. They held different office jobs such as bank employees, department coordinators, financial assistants, accounting assistants, and secretaries. For this level, the students were required to take two video sessions, two lab sessions, and three test sessions during the academic term.

This group was selected because of its students' characteristics and the level of its syllabus. Preliminary observations found that students of this group possessed a linguistic and pragmatic ability to use English communicatively. These abilities promote extensive interaction with the teacher, which is characterized by exchanging meaning. The students regularly ask for meanings that are indispensable to construct, reconstruct, or complete their utterances; they also try to participate actively in each class activity by answering questions to language exercises, and discussing and performing in activities for language use. Second, the activities in the syllabus at this level seek for students to use English to describe, suggest, express, and deal with information in various communicative functions and use an extended vocabulary.

The observations were video recorded to capture most of what happened in each session; and then transcribed by following Gumperz and Berenz' (1993) conventions to detect particularities in terms of speech acts in the interaction between teacher and students. The researcher was a non-participant in both the activities and planning of the class.

The process of analyzing data follows the Ethnomethodological Conversation Analysis (ECA) proposed by Seedhouse (2004a, 2004b). This type of approach closely describes and analyzes details from data in talk-in-interaction. The primary interest of ECA is not in the linguistic aspects of interaction but in the social acts that occur in interactions (see also Schegloff, 1999; Markee, 2000; Cameron, 2001). Social acts are understood as all those utterances, or set of utterances, that serve as a function in communication (Schegloff, 1999; Seedhouse, 2004a).

The analysis of this research was data-driven and followed the ECA principles and sequential stages (Schegloff, 1999; and Seedhouse, 2004a, 2004b). The contextual details of the observations were relevant in the analysis when the interactants brought to light any orientation to such details. As well, every utterance in the structure of the patterns encountered in the excerpts was seen at the discourse level and not at the utterance level. This means that the discourse level of the utterance was the one which revealed its function in the structure of the interactional patterns described in the findings.

\section{Findings}

Analyzing the data from the transcribed sessions revealed two interactional patterns: 1) asking about content, and 2) adding content.

\section{Asking about Content}

In this interactional pattern, a student asks the teacher for an explanation or clarification about the content of a linguistic exercise. The purpose of the student's question is a desire to know more about the parts (lexical items, grammar structures, pronunciation) that 
compose the content of the linguistic exercise. This interactional pattern emerges and is coconstructed between the teacher and a student in either of these two moments in class: a) when the students are doing linguistic exercises, or b) when the teacher is correcting the answers of those exercises with the students.

Those linguistic exercises include:

- Answering questions, in written or oral form, about the content of a reading exercise or a listening exercise.

- A pronunciation drill.

- A grammar-focused exercise.

These types of linguistic exercises reach the level of classroom interaction when students ask the teacher for explanation and further understanding of the parts (lexical items, grammar structures, pronunciation) that compose the content of the linguistic exercise. This means that the interchange of utterances does not focus on the rehearsal of grammar or pronunciation drills. Quite the opposite, the interaction centers its attention on understanding the content of drilling. The part of the content that the student asks about becomes the topic of the interaction.

The reason this interactional pattern takes place in class is because the student needs, in any of the three linguistic exercises, teacher's explanations or clarifications about:

- A grammatical structure.

- The correct way of pronouncing lexical items.

- An unknown lexical item in the TL.

The following table shows a sample excerpt that helps describe the structure of this interactional pattern:

Table 1. Asking about Content Interactional Pattern Structure

\begin{tabular}{|l|l|}
\hline \multicolumn{1}{|c|}{ Excerpt 1} & \multicolumn{1}{|c|}{ Structure of the Interactional Pattern } \\
\hline $\begin{array}{l}\text { [[The teacher is correcting a linguistic exercise of pas- } \\
\text { sive voice with the whole class]] } \\
\text { (01) T: ...yes their product was placed yes was placed } \\
\text { [[as the teacher writes on the board]] was placed. } \\
\text { Placed is also a verb. Was placed. (3 sec.) Clear? }\end{array}$ & $\begin{array}{l}\text { The students are doing the exercise or the teacher is } \\
\text { correcting the exercise. }\end{array}$ \\
\hline $\begin{array}{l}\text { (02) S: no. When do you when do you:: use eh... was } \\
\text { is the:: the product they they? }\end{array}$ & a. A student asks the teacher for explanation. \\
\hline $\begin{array}{l}\text { (03) T: because you refer to the... [[The teacher ad- } \\
\text { dresses to the whole class]] (3 sec.) product: Yes. } \\
\text { To the product. You TALK about the product. They } \\
\text { is not. They is not, you just refer to the product, and } \\
\text { the product is singular. And then the computers } \\
\text { were made were made [[as the teacher writes on the } \\
\text { board]]. Clear? [[The teacher addresses to the whole } \\
\text { class]] (6 sec.) }\end{array}$ & tion. \\
\hline $\begin{array}{l}\text { (04) S: yes } \\
\text { [[The teacher goes on correcting the exercise with the } \\
\text { whole class]] }\end{array}$ & c. The student acknowledges the explanation. \\
\hline
\end{tabular}

The question about the grammatical structure (passive voice in this excerpt) happens in turn 02 of the excerpt when the student takes advantage of the room opened by the teacher to ask her for further explanation about the grammatical structure. As soon as the student has finished her question, the teacher begins, in turn 03, her explanation. To verify if her explanation has been 
understood, the teacher asks the student. In the next turn (04), the student's affirmative answer finishes the interaction.

During any of the linguistic exercises, when the students are doing the exercise or the teacher is correcting it, any student of the class may ask the teacher for explanation or clarification about either grammatical structures, the correct pronunciation of lexical items, or unknown lexical items in the TL that are part of the content of the linguistic exercise. It is noticeable in the structure of this interactional pattern that the students ask the questions without the teacher nominating them. After the student's question, the teacher immediately begins her explanation in response. The interaction closes just after the explanation finishes, with the student's acknowledgement.

\section{Speech acts in the pattern}

The speech act analysis of this interactional pattern shows six speech acts take place in the structure developed between the teacher and students during the classroom interaction. Each speech act carries out a function in the development of the structure in accordance with who utters it, either the student or the teacher. The next table indicates the speech acts of the interactional pattern and their respective functions.

Table 2. Speech Acts and their Functions in the Structure of the Interactional Pattern Asking about Content

\begin{tabular}{|c|c|}
\hline $\begin{array}{l}\text { Structure and speech acts } \\
\text { of the Interactional Pattern }\end{array}$ & $\begin{array}{l}\text { Functions of the speech acts } \\
\text { of the Interactional Pattern }\end{array}$ \\
\hline \multicolumn{2}{|l|}{$\begin{array}{l}\text { The students are doing the exercise or the teacher is } \\
\text { correcting the exercise. }\end{array}$} \\
\hline $\begin{array}{l}\text { a. A student asks the teacher for explanation. } \\
\text { Chipping-in + Eliciting }\end{array}$ & $\begin{array}{l}\text { Chipping-in: A verbal or non-verbal item to signal the } \\
\text { taking-up of the turn to ask the teacher about content } \\
\text { of the linguistic exercise. } \\
\text { Eliciting: A question to request a linguistic response } \\
\text { (teacher's explanation or clarification) about content of } \\
\text { the linguistic exercise. }\end{array}$ \\
\hline $\begin{array}{l}\text { b. The teacher provides the student with the explana- } \\
\text { tion. } \\
\text { Answer initiating + Explaining/Clarifying + Closing }\end{array}$ & $\begin{array}{l}\text { Answer initiating: A lexical item that informs the initia- } \\
\text { tion of a response. } \\
\text { Explaining/Clarifying: Statements whose only function } \\
\text { is to make clear or easy to understand an asked item } \\
\text { in the speak-out exercise by describing or giving infor- } \\
\text { mation about it. } \\
\text { Closing: A verbal or non-verbal item to signal that the } \\
\text { response has just finished and that acknowledgement } \\
\text { of it is being expected. }\end{array}$ \\
\hline $\begin{array}{l}\text { c. The student acknowledges the explanation. } \\
\text { Acknowledgement }\end{array}$ & $\begin{array}{l}\text { Acknowledgement: A verbal or non-verbal lexical item } \\
\text { or utterance that indicates that the student has lis- } \\
\text { tened to the teacher's response and that it seems to } \\
\text { answer the question. }\end{array}$ \\
\hline
\end{tabular}

These six speech acts are generally maintained in the interaction between the teacher and students every time the pattern of asking about content emerges during a linguistic exercise in class. The analysis reveals how the teacher and the students use these six speech acts as components of the functional structure of the interaction in this pattern. The potential influence that these speech acts have 
on the teacher's and the students' interactional behavior in class seems to depend a great deal on three aspects:

- What content the student needs to ask the teacher about when the student takes up the turn.

- The level of difficulty at which the student is able to construct the question.

- What content the teacher uses to answer it.

In this interactional pattern, it is noticeable that the students ask about grammatical structures that they have been working on in the linguistic exercise in progress, or the correct pronunciation of a lexical item encountered as part of the content of the exercise, or for the lexical items in the TL that help understand the content of the linguistic exercise. The students' questions generally start with a chipping-in speech act (such as "teacher"); after this speech act, in the eliciting speech act, the student asks the teacher a question about the aspect of content in the linguistic exercise that needs further explanation or clarification. The student knows that $\mathrm{s} /$ he must ask in the most understandable way possible by using the TL. If the student is able to construct the question in the TL without difficulties, s/he will not have much trouble uttering it; however, if the student experiences difficulties in constructing the question in the TL, the data shows that the student uses either the lexical items in the TL that best describe what $\mathrm{s} /$ he needs to ask or uses his/her first language to make the question. In both cases, the student faces the interactional obligation of keeping the interaction going.

Whichever strategy the student uses to ask, the purpose of his/her question is a desire to know more about the parts (lexical items, grammar structures, pronunciation) that compose the content of the linguistic exercise. Thus, the student encounters a good opportunity to use the TL by asking for a better understanding of the language situation that is happening around him/her.

As for the teacher, she feels the necessity to answer the student's question in the best way possible, with respect to content, syntax, and pronunciation. The explaining/clarifying speech act for this teacher's turn thus contains the most appropriate response that the teacher thinks she can provide in the moment of the student's question. Similar to what the student does during question-making, the teacher uses the language occurring during the discussion to construct the explanation or clarification. The teacher utilizes the strategy of contextualizing the explanation with concepts encountered in the reading, grammar, listening or pronunciation exercise, or with events that happened previously in class, or also with events that the students are familiar with outside the context of the classroom.

The closing following the response (made by nomination or confirmation marks such as "clear?" or "ok?") signals to the student that the answer has just finished and that the teacher is then expecting acknowledgement of it. These types of a closing speech act from the teacher seem to leave the student with no other alternative than acknowledging the teacher's response. As soon as the student does it, the interaction finishes. In the data, the students acknowledge the explanation by accepting it as an answer to the question.

The whole process shows the student asking the teacher about the content of the linguistic exercise in progress because the student needs the teacher's explanation or clarification to succeed in the performance and understanding of the exercise. No matter how the student asks, the content the student inquires about is necessary to follow through with the linguistic exercise. If it is about grammar, the student asks the teacher to understand the grammar of the linguistic exercise. 
In the same way, if it is a pronunciation drill, the question seeks to carry out the exercise with the most accurate knowledge of the pronunciation of the lexical items. And, if it is a vocabulary exercise, the student asks to comprehend additional lexical items to be able to give full meaning to the statements in the linguistic exercise. Finally, the teacher's explanation or clarification is the link for understanding the content of the exercise. This situation is evident in the student's acknowledgement of the teacher's response to his/her question.

To sum up, the interactional pattern of "asking about content" emerges when the students need the teacher's explanation or clarification about the content of a linguistic exercise. The six speech acts in the interactional pattern are generally present in the interaction every time a student asks about content during a linguistic exercise in this class. The potential influence that the six speech acts have on the teacher's and the students' interactional behavior seems to depend on four aspects: on the intention of each speech act within the interactional pattern, on what content the student needs to ask the teacher about, on the level of difficulty at which the student can construct the question, and on what content the teacher uses to answer it.

\section{Adding Content}

In this interactional pattern, a student, or a number of students, add(s) content to an item within a speak-out exercise. This interactional pattern is co-constructed between the teacher and the students when the teacher, in a whole class context, is explaining or clarifying an item that takes part in the speak-out exercise and then opens space for the students to contribute with more content to that item. The item may be about a comment, a fact, or a situation that takes part in the speak-out exercise. As the next move, a student, or a number of students, take(s) up the turn to add content to that item. The teacher then evaluates or accepts the student's contribution and then continues with the speak-out activity. The structure of this interactional pattern thus looks like this:

Table 3. Adding Content Interactional Pattern Structure

\begin{tabular}{|l|l|}
\hline \multicolumn{1}{|c|}{ Excerpt 2} & \multicolumn{1}{|c|}{ Structure of the Interactional Pattern } \\
\hline [[The teacher is explaining an item in the activity]] & $\begin{array}{l}\text { An item takes place in the activity. The teacher ex- } \\
\text { plains or clarifies the item. }\end{array}$ \\
\hline $\begin{array}{l}\text { (01) T: ok for example in January we have winter time, } \\
\text { right? }\end{array}$ & $\begin{array}{l}\text { a. The teacher opens room for the students' contribu- } \\
\text { tions. }\end{array}$ \\
\hline $\begin{array}{l}\text { (02) S: because in Colombia we no have winter sta- } \\
\text { tion. }\end{array}$ & b. A student adds content to the item. \\
\hline $\begin{array}{l}\text { (03) T: ok yeah in Colombia we don't have winter, yes } \\
\text { it's true, so here we have summer all:: year long. Ok } \\
\text { so let's listen to the same part [[the teacher plays the } \\
\text { part of the video on again]] so please listen, listen... }\end{array}$ & $\begin{array}{l}\text { c. The teacher evaluates or accepts the student's } \\
\text { contribution. }\end{array}$ \\
\hline
\end{tabular}

Notice that in the interactional pattern asking about content, the students were involved in a linguistic exercise. This means that the students were exposed to both theoretical and practical applications of the TL (grammar structures, pronunciation, and vocabulary). In contrast to the "asking about content pattern", in the adding content interactional pattern, the 
students are exposed to speak-out exercises. These are class activities that are designed to maximize interaction and verbal output (Stern, 1983) by providing language contexts in which the students can practice and use the TL orally. Some examples of such contexts are student presentations, debates, discussions, and roleplays, among others (see Harmer, 2007, for a more detailed explanation of these activities).

This interactional pattern is developed in two modes depending on the number of students adding content to the item within the speak-out exercise. The first mode takes place when there is only one student in the class adding content to the item at the moment the teacher opens up space for contributions (as the excerpt 2 shows). The second mode takes place when the teacher opens room for the students' contributions and there are a number of students at a time adding content to the item. When this happens, the teacher sorts out one by one, by nomination, the students who are to add content to the item; then, the teacher calls on the students for their contributions, one at a time, in the order she allocated the turns. Both the teacher and the students adopt this strategy and maintain it as a mechanism of class control and fairness, allowing all the students to add content to the item under discussion.

In either mode, the teacher equally evaluates or accepts every student's contribution after each one has participated. When all the students have added content, the teacher goes on with the speak-out exercise. Despite the fact that there are a number of students adding content at a time, the structure of the interactional pattern is maintained.

\section{Speech acts in the pattern}

The speech act analysis of this interactional pattern shows four speech acts taking place in the structure developed between the teacher and students during classroom interaction. Each speech act carries out a function in developing the structure in accordance with who utters it, either the teacher or the student. The next table indicates the speech acts of this interactional pattern and their respective functions.

Table 4. Speech Acts and their Functions in the Structure of the Interactional Pattern Asking about Content

\begin{tabular}{|l|l|}
\hline Structure and speech acts of the Interactional Pattern & \multicolumn{1}{|c|}{$\begin{array}{c}\text { Functions of the speech acts of the Interactional } \\
\text { Pattern }\end{array}$} \\
\hline $\begin{array}{l}\text { An item takes place in the activity. The teacher } \\
\text { explains or clarifies the item. } \\
\text { Explaining/Clarifying }\end{array}$ & $\begin{array}{l}\text { Explaining/Clarifying: Statements whose only function is } \\
\text { to make an item in the speak-out exercise clear or easy to } \\
\text { understand by describing or giving information about it. }\end{array}$ \\
\hline $\begin{array}{l}\text { a. The teacher opens room for the students' } \\
\text { contributions. } \\
\text { Eliciting/Nominating }\end{array}$ & $\begin{array}{l}\text { Eliciting/Nominating: A question or the name of a student } \\
\text { to request for a linguistic response (student's contribution) } \\
\text { about the item emerges in the speak-out exercise. }\end{array}$ \\
\hline $\begin{array}{l}\text { b. A student adds content to the item. } \\
\text { Contributing }\end{array}$ & $\begin{array}{l}\text { Contributing: A (set of) statement(s) voluntarily expressed } \\
\text { to add appropriate content to the item in question. }\end{array}$ \\
\hline $\begin{array}{l}\text { c. The teacher evaluates or accepts the stu- } \\
\text { dent's contribution. } \\
\text { Evaluating/Accepting }\end{array}$ & $\begin{array}{l}\text { Evaluating/Accepting: A verbal or non-verbal lexical item } \\
\text { or utterance that indicates that the teacher has listened to } \\
\text { the student's response and that it seems to be appropri- } \\
\text { ate as content to the item in question. }\end{array}$ \\
\hline
\end{tabular}


The analysis reveals how the teacher and the students use these four speech acts and their functions as components of the interaction in this interactional pattern. The teacher and students normally express these four speech acts and their functions in the interaction every time the pattern of adding content emerges during a speak-out exercise in class. It is remarkable how the two modes (individual contribution and multiple contributions) present the same sequential development of the speech acts every time one student adds content to the item in question. However, in the mode of multiple contributions, the teacher does not necessarily repeat the explaining/clarifying speech act every time she nominates a student for her/his contribution. The question about the item remains within the current episode and becomes explicit with the teacher nominating the student to add content.

The potential influence that these types of speech acts have on the teacher and students' interactional behavior in class is in harmony with the dynamics of the speak-out exercise. Generally, in an exercise of this kind, the teacher is the one who introduces, explains, and controls the mechanics of the class activity (Johnson, 1995). Therefore, it is the teacher who usually provides the description of the language contexts in which the students will practice and use the TL orally.

In this interactional pattern, the teacher's explanation or clarification of an item that has emerged in the speak-out exercise requires that the teacher awaits or asks the students for their opinions, experiences, or viewpoints about the item. This is the reason the teacher creates the questions or nominates as she provides space for the students to add content to the item under discussion. The teacher's questions for this interactional pattern show that she solicits the students' ideas with her question, rather than revealing outright an attempt to test the students' TL proficiency or knowledge of a grammar pattern. As a result, the students answer accordingly. In addition, the students in this group seem to understand that the teacher expects their contributions whenever she explains or clarifies about an item that takes place in a speak-out exercise and asks them about it. This is noticeable in the prompted contributions of the students during the sessions observed.

After any student has added content to the item, the teacher evaluates or accepts the student's contribution by any of these two manners: 1) by paraphrasing, repeating, or agreeing with what the student has said; and 2) by adding further content such as her opinions, experiences, or viewpoints about the item.

The teacher evaluates or accepts every student's contribution to communicate to the student that her/his contribution has now been heard and that it seems to be appropriate as content to the item in question. In addition, the teacher's speech act serves as an action for both closing the interaction with the current student, and for letting the next student know that an interaction with her/him is about to be opened. In this way, the development of the structure (student's contributing-teacher's evaluating/ accepting) is maintained. When there are not more students to participate, this teacher's speech act serves to end the episode and go on with the next activity for the class. When this happens, this last teacher's action indicates to the students that no more contributions for the current item are expected.

In sum, in this interactional pattern, a student (or a number of students) adds content to an item during a speak-out exercise. The four speech acts of this pattern of adding content develop consecutively, one being the result of the previous one. They frequently emerge and are maintained when the teacher first explains or clarifies an item that takes place during a speak-

Colomb. Appl. Linguist. J. 
out exercise, she then opens up room for the students to add content to that item. This action influences the students' interactional behavior since this leads them to contribute with what the teacher requests. The students' contributions also make the teacher provide a response to the students' actions. The response is the evaluation or acceptance of the contribution. In this way, the structure of this interactional pattern is completed and both interactants feel they have accomplished their respective roles in the classroom interaction thus far.

\section{Teacher's Regulatory Speech Act in Both Interactional Patterns}

In the explanation of how the two interactional patterns develop through their speech acts, one utterance follows the other in synchrony, constructing in this way the organized structure of the interactional patterns. However, this is not what always happens every time either of the two interactional patterns takes place in the interaction between the teacher and students in class. The data analysis shows that a teacher's regulatory speech act can slightly alter the two interactional patterns.

According to Wunderlich (as cited in Searle, Kiefer, E Bierwish, 1980, p. 297), this speech act is a speech unit that may arise in a type of institutional discourse with the purpose of regulating the speaker's conduct, in accordance with the task of the institutional speech activity. It means that the regulatory speech act is a pattern that belongs to the task of the institutional speech activity, and contributes to the structure of the interaction.

This teacher's speech act emerges and is then maintained in both interactional patterns when the student does not fulfill either of the following two established conventions of the class: 1) the student does not add a detailed amount of content to the item in question in a speak-out exercise; and 2) the student does not use the TL for his/her contribution in a speak-out exercise or for his/her question in a linguistic exercise. In both cases, the structure of the interactional patterns is slightly altered:

Table 5. The Structure of the Interactional Patterns with a Teacher's Regulatory Speech Act

\section{Linguistic Exercise}

\section{Speak-out Exercise}

\begin{tabular}{|c|c|}
\hline $\begin{array}{l}\text { The students are doing the exercise or the teacher } \\
\text { is correcting the exercise. }\end{array}$ & $\begin{array}{c}\text { An item takes place in the activity. The teacher } \\
\text { explains or clarifies the item. }\end{array}$ \\
\hline $\begin{array}{l}\text { a. A student asks the teacher for explanation (without } \\
\text { following the established conventions of the task). } \\
\text { 1. The teacher demands the TL use (Regula- } \\
\text { tory). } \\
\text { 2. The student uses the TL for the question } \\
\text { (Translated Elicit) }\end{array}$ & $\begin{array}{l}\text { a. The teacher opens up room for the students' contri- } \\
\text { butions. }\end{array}$ \\
\hline $\begin{array}{l}\text { b. The teacher provides the student with the explana- } \\
\text { tion. }\end{array}$ & $\begin{array}{l}\text { b. A student adds content to the item (without follow- } \\
\text { ing the established conventions of the task). } \\
\text { 1. The teacher demands expansion of content } \\
\text { or the TL use (Regulatory). } \\
\text { 2. The student adds more content to the item } \\
\text { (Amplified Contribution) or uses the TL for } \\
\text { the contribution (Translated Contribution). }\end{array}$ \\
\hline c. The student acknowledges the explanation. & $\begin{array}{l}\text { c. The teacher evaluates or accepts the student's } \\
\text { contribution. }\end{array}$ \\
\hline
\end{tabular}


The teacher's regulatory speech act that takes part in both interactional patterns is generally a verbal or non verbal lexical item or a (set of) statement(s) whose function is to urge the student to re-take the performance with the established conventions of the speak-out exercise or the linguistic exercise (TL use or amplified contribution). Sequentially, the student's amplified contribution is a (set of) statement(s) that expand in stating or describing the same student's contribution to the item in question in the speak-out exercise. The student's translated elicit or contribution is the same student's question or (set of) statement(s), but now translated into the $\mathrm{TL}$, with the function of asking about the content of the linguistic exercise or adding appropriate content to the item in question in the speak-out exercise.

In the following excerpts, it is evident how the teacher's regulatory speech act (in italics) takes part in both interactional patterns.

Table 6. The Teacher's Regulatory Speech Act in both Interactional Patterns

Adding Content (Amplified contribution)

\begin{tabular}{|l|}
\hline \multicolumn{1}{|c|}{ Excerpt 3} \\
\hline [[The class is about paintings]] \\
(01) T: Ok Sarah DO YOU have religious paintings in \\
your house? \\
(02) S: [[S3 shakes her head]] \\
(03) T: No... [[teacher moves her right hand in circles]] \\
(04) S: no... because... eh... no interesting. Religious \\
not is for me. \\
(05) T: Ok thank you. \\
\end{tabular}

In excerpt 3, the student's contribution (turns 02 and 04) is, say, compound, because it happens in two turns, the first of which does not fulfill the conventions of the task and which the teacher does not consider a complete contribution, and the second, which is a complete contribution due to the intervention of the teacher's regulatory speech act. In excerpt 4 , the student translates the question into the TL. In both excerpts, the subsequent teacher's speech acts (evaluating/ accepting and answer initiating) increase their functions through indicating that the student's earlier contribution or question now seem to fulfill the established conventions of the exercise.

In both interactional patterns, the potential influence that the teacher's regulatory speech act exercises is basically the content following after the student's initial contribution that did not fulfill the established conventions of the
Asking about Content (TL use)

Excerpt 4

[[The teacher is explaining on the board]]

(01) T: ...needed, this one, if I needed if I needed to

lose weight I would avoid fatty food, clear? Ok

(02) S: dos verbos, en pasado y presente?

(03) $\mathrm{T}$ : in English

(04) S: the two verbs in past the first eh was in past?

And second in present or...?

(05) T: Ok. Remember that you asked me last class if the first verb is in past...

exercise. This regulatory speech act occurs not only by demanding an amplified/translated (set of) statement(s) from the student but also by providing him/her with another opportunity to use the TL in the interaction. The teacher seems not to use this speech act to assess the student's target language proficiency or accuracy at all. This is evident in the subsequent turns in which the focus of the interaction continues to be on the meaning that the speech acts communicate in the rest of the structure.

Considering the student's position, the anxiety this situation generates makes his/her interactional behavior change. If the student is, let us say, proficient enough to put his/her contribution or question into the target language, few problems occur - just some hesitant speech, use of casual words, or short pauses. If the student is less proficient, his/her translated contribution 
or elicit may show recurrently faltering speech or longer pauses. The student may even turn to the teacher for help constructing his/her contribution or question.

\section{Conclusions and Pedagogical Implications}

This research does not look to assess the observed teacher's or the students' talk in classroom interaction. On the contrary, the purpose resides in making clear that both interactants display interactional behaviors in the TL with a certain level of conversational competence that shape classroom interaction. Therefore, the interactional patterns that emerge and are then maintained in the class observed are points of reference to interpret conversational management in classroom interaction.

Both interactional patterns display how the teacher and the students share responsibility and efforts to carry out the structure of both patterns. Each participant reacts according to the other's utterance and additional aspects of the context of the interaction. This is why each interactional pattern contains a particular set of speech acts that have in turn particular functions and particular interactional behaviors for each interactant, in accordance with the role each interactant assumes and the type of exercise in which the interaction occurs.

Thus, distinctive speech acts exist for each participant that reinforce his/her role in classroom interaction. The function of each speech act in the structures of the two interactional patterns, each with its manner of conversational management reflecting the intentions, goals, and roles of the teacher and students in the classroom interaction, confirm this point. Although both the teacher and the students assume an active role in coconstructing the interaction (albeit with different responsibilities), the teacher's role is central and leading since she is the one who mostly sets the topic and engages the students to take part in class through initiating interactions. On the other hand, the students' role is the reflection of the teacher's central and leading role since, prompted by it, the students project their speech acts in the classroom interaction. This study demonstrates that the teacher must skillfully conduct classroom interaction since $s /$ he seems to be the one who provides the students' opportunities to use and learn the TL through the explaining/clarifying, eliciting/nominating, and regulatory speech acts.

However, in this process, the speech act that mostly influences the students' interactional behavior is the teacher's regulatory speech act, even though this speech act does not interrupt the communicative interaction in progress. This speech act regulates the student's participation by urging the student to perform the established conventions of either adding a detailed amount of content to the item in question or using the target language in the exercise. The teacher's regulatory speech act puts the student in an uneasy position in which $\mathrm{s} /$ he must carry out in his/her participation the established convention solicited. In order to do this, the student has to "revisit" his/her previous participation in the interaction and say it again, but now carrying out the established convention. This study shows the great value in teachers using regulatory speech acts to keep focus on the communication of meaning. If teachers attempt to control the students' language accuracy according to the demands of convention, then the students will lose sight and the practice of using the TL for communication.

Consequently, the established conventions of the exercise do play a relevant role in the way the teacher and students render their speech acts that construct each interactional pattern. It can then be said that the established conventions of the exercise are the background framework within which the class activities surface. As this article 
has discussed, it is during classroom exercises that the teacher and students co-construct and maintain the two interactional patterns described here with their characteristic speech acts.

The facts presented up to this point lead this discussion to conclude that once a particular interactional pattern with its speech acts emerges in classroom interaction, the teacher and students then try to maintain it as a structure that should be carried out. The findings demonstrate this in two moments: when a student asks the teacher a question about the content of the exercise, and when the teacher requests the students to add content to the exercise, with the potential slight alteration of both moments if a student fails to perform an established convention.

\section{References}

Austin, J.L. (1975). How to do Things with Words (2 ${ }^{\text {nd }}$ ed.). Oxford: Clarendon Press.

Clark, H.H., \& Schaefer, E.F. (1989). Contributing to Discourse. Cognitive Science, 13, 259-294.

Cameron, D. (2001). Working with Spoken Discourse. London: Sage.

Ellis, R. (1994). The Study of Second Language Acquisition. New York: Oxford University Press.

Ellis, R., \& Sheen, Y. (2006). Reexamining the role of recast in Second Language Acquisition. SSLA, 28, 575-600.

Garton, S. (2002). Learner initiative in the language classroom. ELT Journal, 56 (1), 47-56.

Gibbons, P. (2006). Bridging Discourses in the ESL Classroom. New York: Continuum.

Gumperz, J., \& Berenz, N. (1993). Transcribing conversational exchanges. In J. Edwards \& M. Lumpert (Eds.), Transcription and Coding Methods for Language Research (pp. 109-144). Hillsdale, $\mathrm{NJ}$ : Lawrence Earlbaum Associtates Inc.

Harmer, J. (2007). How to Teach English. Harlow, UK: Pearson Longman Education.

Ilatov, Z. Z., Shamai, S., Hertz-Lazarovitz, R., \& MayerYoung, S. (1998). Teacher-student classroom interactions: The influence of gender, academic domi- nance, and teacher communication style. Adolescence, 33(130), 269-277. Retrieved from ProQuest Medical Library, (AAT 32612446).

Johnson, K. (1995). Understanding Communication in Second Language Classrooms. New York: Cambridge University Press.

Kurhila, S. (2006). Second Language Interaction. Philadelphia: John Benjamin Publishing Company.

Leech, G. (1983). Principles of Pragmatics. Harlow: Longman.

Long, M. H. (1996). The role of the linguistic environment in second language acquisition. In W. R.

Ritchie \& T. K. Bhatia (Eds), Handbook of Second Language Acquisition (pp. 413-468). San Diego: Academic Press.

Long, M., \& Sato, C. (1983). Classroom foreigner talk discourse: Forms and Functions of teachers' questions. In H. Seliger \& M. Long (Eds.), Classroom Oriented Research in Second Language Acquisition (pp. 268-265). New York: Newbury House.

Lyster, R. (1998). Recasts, repetition, and ambiguity in L2 classroom discourse. Studies in Second Language Acquisition, 20, 51-81.

Mackey, A. \& Philp, J. (1998). Conversational Interaction and Second Language Development:Recasts, Responses and Red Herrings? Modern Language Journal. 82(3), 338-356.

Markee, N. (2000). Conversation Analysis. Mahwah, NJ: Lawrence Erlbaum Associates Inc.

McCarthy, M. (1991). Discourse Analysis for Language Teachers. Cambridge: Cambridge University Press.

Richards, J., \& Lockhart, C. (1994). Reflective Teaching in Second Language Classroom. New York: Cambridge University Press.

Rivers, W. (1983). Communicating Naturally in a Second Language. Cambridge: Cambridge University Press.

Schegloff, E. (1999). Discourse, pragmatics, conversation, analysis. Discourse Studies, 1(4), 405435.

Schegloff, E. (2000). When others initiate repair. Applied Linguistics, 21(2), 205-243.

Searle, J.R. (1969). Speech Acts. New York: Cambridge University Press.

Searle, J.R. (1979). Expression and Meaning. New York: Cambridge University Press.

Seedhouse, P. (2004a). The Interactional Architecture 
of the Language Classroom: A Conversation Analysis Perspective. Madison, USA: Language Learning Monograph Series.

Seedhouse, P. (2004b). Conversation Analysis Methodology. Language Learning, 54(1), 1-54.

Sinclair, J., \& Coulthard, R.M. (1975). Towards an Analysis of Discourse: The English Used by Teachers and Pupils. Oxford: Oxford University Press.
Stern, H.H. (1983). Fundamental Concepts of Language Teaching. Oxford: Oxford University

Press.

Van Lier, L. (1988). The Classroom and the Language Learner. New York: Longman.

Wunderlich, D. (1980). Methodological remarks in Speech Act Theory. In J. Searle, F. Kiefer, \& M. Bierwish (Eds.). Speech Act Theory and Pragmatics (pp. 290-312). Dordrecht, Holland: D.

Reidel Publishing Company.

THE AUTHOR

EDGAR LUCERO holds an M.A. in Applied Linguistics from Universidad Distrital. He teaches Discourse Analysis, Research, and Didactics in the BA program in English Language Teaching at Santo Tomas University in Bogota. His research interests are in classroom interaction, and evaluation processes of English as a Foreign Language. He is a researcher in the group of English Didactics at Santo Tomas University. 